\title{
Plant growth, accumulation and solute partitioning of four forest species under salt stress
}

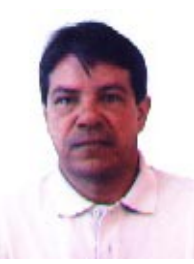

Ricardo A. Viégas' ${ }^{1}$, José E. Queiroz' ${ }^{1}$ Lígia M. de M. Silva1', Joaquim A. G. Silveira², Iza M. A. Rocha² \& Pedro R. A. Viégas ${ }^{3}$

\footnotetext{
1 Laboratório de Nutrição Florestal e Estresse de Plantas, Depto. de Engenharia Florestal da UFCG. CP 64, CEP 58700-970, Patos, PB. E-mail: rviegas221@globo.com (Foto)

${ }^{2}$ Laboratório de Metabolismo e Estresse de Plantas, Depto. de Bioquímica e Biologia Molecular da UFC. CP 6020, CEP 60451-970, Fortaleza, CE. E-mail: silveira@ufc.br

${ }^{3}$ Laboratório de Nutrição Mineral de Plantas, Departamento de Agronomia da UFS. CP 12, CEP 55100-00, Aracaju, SE. Email: pviegas@ufs.br
}

Protocolo 197 - 30/12/2002 - Aprovado em 18/8/2003

\begin{abstract}
Under $\mathrm{NaCl}$-salinity $\mathrm{Na}^{+}$and $\mathrm{Cl}^{-}$accumulation of shoot and root vary greatly among glycophyte plants; this is mostly due to genetic diversity and has been utilized to distinguish between plant responses to salinity. The current study aimed to evaluate the accumulation and $\mathrm{Na}^{+}$and $\mathrm{Cl}^{-}$tissue partitioning and its effect on dry mass gain and $\mathrm{K}^{+}$accumulation in onemonth-old Prosopis juliflora, Leucaena leucocephala, Piptadenia macrocarpa and Mimosa hostilis seedlings grown for 30 days, in sand watered with nutrient solution loading $100 \mathrm{~mol} \mathrm{~m}^{-3}$ of $\mathrm{NaCl}$, in greenhouse. The $\mathrm{Na}^{+}$and $\mathrm{Cl}^{-}$accumulation, but not partitioning between shoot and root, depended on plant species. All the plants accumulated $\mathrm{Cl}^{-}$over $\mathrm{Na}^{+}$both in shoot and root. The $\mathrm{K}^{+}$content of plants did not significantly vary in shoot but decreased in root due to salinity. The ability of these plants to avoid damaging the metabolism due to salinity may result, in part, from a high shoot $-\mathrm{K}^{+}$to $\mathrm{Na}^{+}$ratio. Leucaena leucocephala had the higher decrease of total dry matter $(60 \%)$ and lower shoot- $\mathrm{K}^{+}$to $\mathrm{Na}^{+}$ratio $(0.40)$, while Prosopis juliflora had lower decrease of total dry matter $(15 \%)$ and had $\mathrm{K}^{+}$to $\mathrm{Na}^{+}$ratio of shoot about 3 times more. Evidence is presented supporting a role for increased $\mathrm{K}^{+}$to $\mathrm{Na}^{+}$ratios in adaptation of plants to osmotic and ionic stresses.
\end{abstract}

Key words: salinity, potassium, sodium, chloride

\section{Crescimento, acumulação e distribuição de solutos em espécies florestais sob estresse salino}

Resumo: Em condições de estresse salino a acumulação de $\mathrm{Na}^{+}$e $\mathrm{Cl}^{-}$, na parte aérea e nas raízes, difere substancialmente entre plantas glicófitas; este fato deve-se, principalmente, à diversidade genética existente e tem sido utilizado como indicador da resposta das plantas à salinidade. Este estudo objetivou avaliar a acumulação e a distribuição de $\mathrm{Na}^{+}$e $\mathrm{Cl}^{-}$, bem como o efeito da salinidade sobre o ganho de massa seca e a distribuição de $\mathrm{K}^{+}$, na parte aérea e raízes, em plantas jovens de Prosopis juliflora, Leucaena leucocephala, Piptadenia macrocarpa e Mimosa hostilis, com um mês de idade, cultivadas durante 30 dias em areia e irrigadas com solução nutritiva contendo $100 \mathrm{~mol} \mathrm{~m}^{-3} \mathrm{NaCl}$, em casa de vegetação. A acumulação de $\mathrm{Na}^{+}$e $\mathrm{Cl}^{-}$ , e não a distribuição desses íons entre parte aérea e raízes, foi dependente da espécie de planta. Em todas as espécies estudadas a acumulação de $\mathrm{Cl}^{-}$na parte aérea e nas raízes foi maior que a de $\mathrm{Na}^{+}$. A exceção da parte aérea, todas as plantas apresentaram redução significativa no conteúdo de $\mathrm{K}^{+}$nas raízes em resposta à salinidade. A habilidade dessas plantas em proteger o metabolismo do efeito deletério da salinidade pode resultar, em parte, de uma alta relação $\mathrm{K}^{+}$/ $\mathrm{Na}^{+}$. Desta forma, a Leucaena leucocephala apresentou a maior redução na produção da massa seca total $(60 \%)$ e a menor relação $\mathrm{K}^{+} / \mathrm{Na}^{+}$na parte aérea $(0,40)$ enquanto que a Prosopis juliflora apresentou a menor redução na massa seca total $(15 \%)$ e uma relação $\mathrm{K}^{+} / \mathrm{Na}^{+}$na parte aérea, aproximadamente três vezes maior. Esses resultados sugerem que maiores relações $\mathrm{K}^{+} / \mathrm{Na}^{+}$ desempenham um importante papel na adaptação da planta aos estresses iônico e osmótico.

Palavras-chave: salinidade, potássio, sódio, cloreto 


\section{INTRODUCTION}

The effects of salinity on plant growth have extensively been a focus of research because of salt response of plants is a complex phenomenon that involves several physiological and biochemical changes (Hasegawa et al., 2000; Ghoulam et al., 2002). Ionic imbalance occurs in the cell due to excessive accumulation of $\mathrm{Na}^{+}$and $\mathrm{Cl}^{-}$and reduces the uptake of other mineral nutrients such as $\mathrm{K}^{+}$and $\mathrm{NO}_{3}^{-}$(Viégas et al., 1999). It has been suggested that $\mathrm{Na}^{+}$and $\mathrm{Cl}^{-}$accumulation in root over shoot could be useful as indicator of salinity tolerance of plants (Silveira et al., 2001). The best manifestation of this is exemplified by those cases in which gain in dry mass were associated with decreased accumulation of $\mathrm{Na}^{+}$and $\mathrm{Cl}^{-}$in shoot of some woody plants in the early seedling phase (Teleinskk \& Grunberg, 1994; Souza et al., 2002; Fausto et al., 2002).

The exclusion of $\mathrm{Na}^{+}$from shoot and its preferential accumulation in root has been observed in 'cumaru' (Souza et al., 2002), 'algaroba' (Fausto et al., 2002), 'umbu' (Paulo et al., 2002) and cashew (Viégas et al., 1999). In the later case, $\mathrm{Na}^{+}$ exclusion occurs from young to either old leaves or root but only in the earlier stages of salinity stress. According to Viégas et al. (1999), this process is disrupted in cashew plants due to displacement of root- $\mathrm{Ca}^{2+}$ by $\mathrm{Na}^{+}$, resulting in a change of plasma membrane permeability (Lin et al., 1997). This could induce increase in net uptake of $\mathrm{Na}^{+}$, allowing down hill influx of $\mathrm{Cl}^{-}$into cell of plant tissues (Skerrtt \& Tyerman, 1992). Because of this $\mathrm{Na}^{+}$and $\mathrm{Cl}^{-}$uptake has been suggested to be a process highly coordinated (Viégas et al., 1999).

The $\mathrm{Ca}^{2+}$ displacement by $\mathrm{Na}^{+}$at plasma membrane may constitute a primary response to salinity stress. Under this condition $\mathrm{K}^{+} / \mathrm{Na}^{+}$selectivity may substantially be altered (Serrano \& Rodriguez-Navarro, 2001). It has been suggested that the interaction between $\mathrm{K}^{+}$and $\mathrm{Na}^{+}$might represent a key factor in determining the salinity tolerance of plants (Buschmann et al., 2000). At the whole plant level, it is generally accepted that increased $\mathrm{K}^{+} / \mathrm{Na}^{+}$selectivity during uptake and reduced $\mathrm{Na}^{+}$translocation from the root to the shoot contribute to the salt tolerance of glycophytes (Rascio et al., 2001). Recent research with mutants of Arabidopsis has shown that the integrity of the $\mathrm{K}^{+}$uptake system plays a role to salt tolerance (Zhu et al., 1998). Higher level of $\mathrm{K}^{+}$in leaf tissue is associated with salt tolerance in cowpea (Silveira et al., 2001). The role of $\mathrm{K}^{+}$is vital for osmorregulation and protein synthesis, maintaining cell turgor and stimulating photosynthesis (Buschmann et al., 2000).

Although increase in soil salinity is one of the major problems confronting agriculture in the semi-arid region of Brazil, research result are scarce and has no or limited information about salinity responses of tree-plants existing in that region. Thus, the purpose of this work was to study the accumulation and $\mathrm{Na}^{+}$and $\mathrm{Cl}^{-}$partitioning and the effect of salinity on dry mass gain and $\mathrm{K}^{+}$accumulation in the early seedling phase of Leucaena leucocephala (Benth.), Prosopis juliflora (Benth.), Mimosa hostilis (Benth.) and Piptadenia macrocarpa (Benth.), common names "leucena", "algaroba", "jurema" and "angico", respectively.

\section{MATERIAL AND METHODS}

\section{Plant material and growth conditions}

Seeds of Prosopis juliflora, Piptadenia macrocarpa, Mimosa hostilis and Leucaena leucocephala were collected from plants grown under field conditions in semi-arid region of Northeastern of Brazil. The seeds were surface sterilized for 15 $\min$ in $5 \% \mathrm{NaOCl}$ and rinsed for $10 \mathrm{~min}$. with running distilled water then sown in sand irrigated daily with $1.0 \mathrm{~mol} \mathrm{~m}^{-3} \mathrm{CaSO}_{4}$ (Silveira et al., 2001). After emergence, 15-day-old homogeneous seedlings of each species were transplanted to plastic pots (20 $\mathrm{cm}$ in long x $30 \mathrm{~cm}$ high) filled with $0.5 \mathrm{~cm}^{3}$ of sand. The pots were kept in well-ventilated greenhouse during the experimental period. Each pot was irrigated daily with $1 / 4$ strength Hoagland \& Arnon (1950) nutrient solution. When seedlings were onemonth-old, irrigation was carried out daily with half strength nutrient solution loading $100 \mathrm{~mol} \mathrm{~m}^{-3}$ of $\mathrm{NaCl}$ during 30 days. Plants irrigated with nutrient solution free of $\mathrm{NaCl}$ were taken as control. The pots were irrigated twice a day until leaching started to avoid salt accumulation. The $\mathrm{pH}$ of nutrient solution was kept in $5.5 \pm 0.2$ range with $\mathrm{HCl}$ or $\mathrm{NaOH}$. The study was carried out without shelter in semi-arid region of Brazil during September/October months. The air temperature and relative humidity in the greenhouse were in the range of 26 to $33^{\circ} \mathrm{C}$ and 35 to $50 \%$, respectively. The maximal intensity of radiance at plant canopy was of $1,500 \mu \mathrm{mol}$ of photons $\mathrm{m}^{-2}$. $\mathrm{s}^{-1}$. After treatment period, the plants were separated into root and shoot. The roots were washed with distilled water, then both plant parts were dried at $90^{\circ} \mathrm{C}$ and properly stored for further analysis of $\mathrm{Na}^{+}, \mathrm{K}^{+}$and $\mathrm{Cl}^{-}$.

The experiment was conducted in a $2 \times 4$ factorial completely randomized design corresponding to $\mathrm{NaCl}$ levels and plant species, respectively, and had six replicates per treatment, each replicate consisting of one plant per pot.

\section{$\mathrm{Na}^{+}, \mathrm{K}^{+}$and $\mathrm{Cl}^{-}$determination}

Dried plant tissue was powdered and subjected to wet digestion with (4:1) $\mathrm{HNO}_{3}: \mathrm{HClO}_{4}(\mathrm{v} / \mathrm{v})$ according to Chapman $\&$ Pratt (1961). The resulting solutions were properly diluted and analyzed for $\mathrm{K}^{+}$and $\mathrm{Na}^{+}$by flame photometer. $\mathrm{Cl}^{-}$was extracted from the dried tissue with water and determined by titration against standard $\mathrm{AgNO}_{3}$ (Malavolta et al., 1989).

\section{Data analysis}

The effects of treatments on plant dry mass accumulation and ion content were performed by ANOVA system. The treatment means were compared by LSD (least significant difference) at the 0.05 confidence level using Tukey test. Standard errors (SE) are reported in the figures. ANOVA results were calculated with the SIGSTAT package.

\section{RESULTS AND DISCUSSION}

Seedlings of four forest species (Prosopis juliflora, Piptadenia macrocarpa, Mimosa hostilis and Leucaena leucocephala) were grown in $100 \mathrm{~mol} \mathrm{~m}^{-3}$ of $\mathrm{NaCl}$ and were evaluated for the early responses to salinity. Salinity provoked 
slight yellowing on leaves already from the $10^{\text {th }}$ day of treatment in Mimosa hostilis and Leucaena leucocephala. The salt symptom was aggravated with increasing exposure time of salinity; the leaves of these two plants exhibited severe necrotic and chlorotic symptoms. In addition, there was significant interaction $(P<0.05)$ between salinity $(\mathrm{S})$ and plant species $(\mathrm{E})$ factors for all studied parameters given below, and this is largely expected due to great genetic diversity of the investigated plants. Particularly, information was sought on the role of these interactions concerning the earlier responses of the plants to salinity.

Dry matter (DM) accumulation of $\mathrm{NaCl}$ grown plants is summarized in Figure 1. The DM gain remarkably differed among plants; for instance, $\mathrm{NaCl}$ did not significantly $(P>0.05)$ affect total DM of Prosopis juliflora and Piptadenia macrocarpa

A.

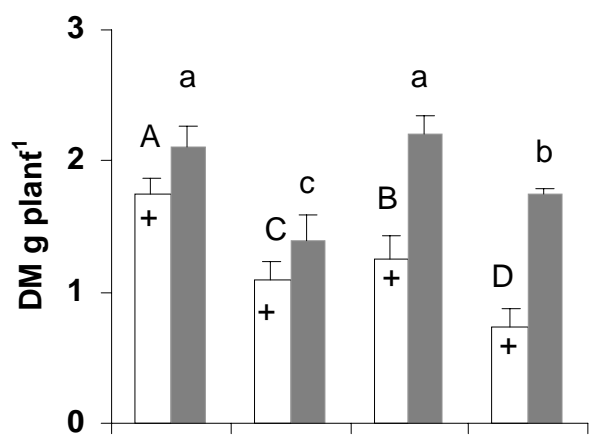

B.



C.

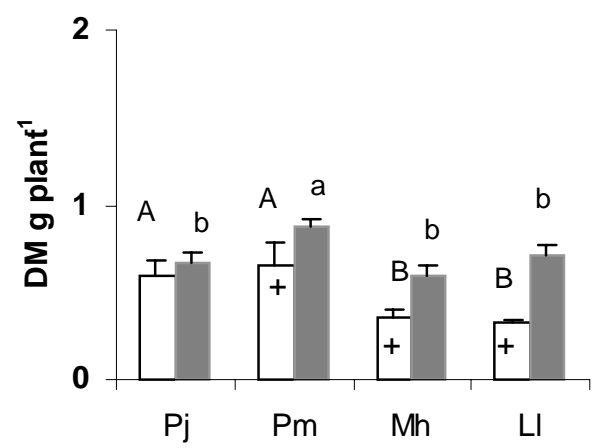

Figure 1. Total (A), shoot (B) and root (C) plant dry mass (DM) of Prosopis juliflora (Pj), Piptadenia macrocarpa (Pm), Mimosa hostilis (Mh) and Leucaena leucocephala (Ll) grown either in absence or presence of $100 \mathrm{~mol} \mathrm{~m}^{-3}$ of $\mathrm{NaCl}$. Means followed by the same capital $(\mathrm{NaCl})$ or tiny (Control) letter are not significantly different at $P>0.05$ (Tukey test). DM, indicates dry mass; + , significant difference between $\mathrm{NaCl}$ and control $(P<0.05)$. Upper bars give $\pm \mathrm{SD}$ contrary to Mimosa hostilis and Leucaena leucocephala (Figure 1A). Total DM of Mimosa hostilis and Leucaena leucocephala had a decrease of 42 and 60\%, respectively, compared to respective controls. Prosopis juliflora and Leucaena leucocephala had the more contrasting results in terms of dry mass partitioning. Prosopis juliflora had a decrease in DM of 14 and $5 \%$ in shoot and root, respectively, compared to controls. Instead, salinity accounted for a decrease in DM in shoot and root of Leucaena leucocephala by 61 and $52 \%$, respectively (Figure 1B, 1C).

The accumulation and $\mathrm{Cl}^{-}, \mathrm{Na}^{+}$and $\mathrm{K}^{+}$partitioning both in tissues and organs are important physiological processes leading to salt tolerance (Schachtman \& Liu, 1999; Serrano \& Rodriguez-Navarro, 2001). Among the studied species, Leucaena leucocephala was observed to accumulate higher amounts of $\mathrm{Na}^{+}$and $\mathrm{Cl}^{-}$in shoot. $\mathrm{Na}^{+}$accumulated in shoot of Leucaena leucocephala reached an amount about 2.6fold higher than the other species (Figure 2A). This indicates for excessive low-affinity $\mathrm{Na}^{+}$uptake, which is toxic to


Figure 2. $\mathrm{Na}^{+}(\mathrm{A}), \mathrm{Cl}^{-}(\mathrm{B})$ and $\mathrm{K}^{+}(\mathrm{C})$ accumulated in shoot and root of Prosopis juliflora $(\mathrm{Pj})$, Piptadenia macrocarpa $(\mathrm{Pm})$, Mimosa hostilis $(\mathrm{Mh})$ and Leucaena leucocephala $(\mathrm{Ll})$ grown either in absence or presence of $100 \mathrm{~mol} \mathrm{~m}^{-3}$ of $\mathrm{NaCl}$. Means followed by the same capital $(\mathrm{NaCl})$ or tiny (Control) letter are not significantly different at $P>0.05$ (Tukey test). DM, indicates dry mass; + , significant difference between $\mathrm{NaCl}$ and control $(P<0.05)$. Upper bars give $\pm \mathrm{SD}$ 
the growth of glycophytic plants (Buschman et al., 2000). In addition, Leucaena leucocephala had the highest content of $\mathrm{Cl}^{-}$in shoot compared to the other species (Figure 2B). This may inhibit some enzymes mostly those involved with $\mathrm{NO}_{3}^{-}$to $\mathrm{NH}_{4}^{+}$reduction (Viégas \& Silveira, 1999). The results from Figures 2A, 2B show still that Prosopis juliflora and Piptadenia macrocarpa had the lower contents of $\mathrm{Na}^{+}$and $\mathrm{Cl}^{-}$in shoot.

Reports have suggested that interaction between internal $\mathrm{K}^{+}$and $\mathrm{Na}^{+}$might represent a key factor in determining the salinity tolerance of plants (Rascio et al., 2001; Silveira et al., 2001). In the current study, the shoot- $\mathrm{K}^{+}$content of plants have not been significantly $(P>0.05)$ changed due to salinity (Figure 2C). In addition, Prosopis juliflora had the higher content of $\mathrm{K}^{+}$in shoot compared to the other ones. On the contrary, increasing in accumulation of salt ions in tissue, particularly $\mathrm{Na}^{+}$, due to salinity, significantly affected the $\mathrm{K}^{+}$content in root of the plants (Figure 2A, B, C). There are physiological evidences suggesting that $\mathrm{Na}^{+}$competes with $\mathrm{K}^{+}$for intracellular influx since both cations share common transporter protein (Hasegawa et al., 2000).

Prosopis juliflora had shoot $\mathrm{K}^{+}$to $\mathrm{Na}^{+}$ratio of 1.16 while Leucaena leucocephala had of 0.40 (Figure 3A). Bottacin et al. (1984), encountered $\mathrm{K}^{+}$to $\mathrm{Na}^{+}$ratios in shoot of 1.46 for the tolerant and of 0.64 for the salt susceptible genotypes; these authors concluded that salt tolerance to be characterized by the ability of plants to maintain $\mathrm{K}^{+}$to $\mathrm{Na}^{+}$ratios of shoot adjusted to $\mathrm{K}^{+}$metabolic requirements. Thus, the salt tolerance of plants is due partly to its ability to avoid accumulation of harmful $\mathrm{Na}^{+}$and/or maintain adequate levels of $\mathrm{K}^{+}$in shoot (Lacerda et al., 2001). In the most general terms, the highest

A.



B.



Figure $3 . \mathrm{K}^{+}$to $\mathrm{Na}^{+}$ratios of shoot (A) and $\mathrm{Na}^{+}$shoot to root ratios (B) of Prosopis juliflora (Pj), Piptadenia macrocarpa $(\mathrm{Pm})$, Mimosa hostilis $(\mathrm{Mh})$ and Leucaena leucocephala $(\mathrm{Ll})$ grown in $100 \mathrm{~mol} \mathrm{~m}^{-3}$ of $\mathrm{NaCl}$. Means followed by the same letter are not significantly different at $P>0.05$ (Tukey test). $\mathrm{DM}$, indicates dry mass. Upper bars give $\pm \mathrm{SD}$
$\mathrm{Na}^{+}$shoot to root ratio observed for Leucaena leucocephala show the roots of this plant were comparatively less able to prevent harmful $\mathrm{Na}^{+}$from reaching the leaves (Figure 3B).

In the present study the higher sensitivity to salinity of Mimosa hostilis and Leucaena leucocephala, in terms of total dry matter gain, could be due partly to the highest contents of $\mathrm{Na}^{+}$and $\mathrm{Cl}^{-}$in shoot and root of these plants (Figures $1 \mathrm{~A}, 2 \mathrm{~A} \mathrm{e} \mathrm{B}$ ). It is interesting to show a preferential accumulation of $\mathrm{Cl}^{-}$over $\mathrm{Na}^{+}$both in shoot and root of the four studied species (Figures 2A e B). This is likely due to increased uptake and furthermore $\mathrm{Na}^{+}$accumulation, possible depolarizing the $\ddot{A} \varnothing$ across plasma membrane which, according to Skerrtt \& Tyerman (1992), allows that $\mathrm{Cl}^{-}$be taken up passively through an anion channel.

It has been established for plant root a dual uptake system of $\mathrm{K}^{+}$with either high or low affinity for $\mathrm{K}^{+}$that adjust with environmental stimulus (Niu et al., 1995; Maathuis et al. 1996). It is possible, as it was seen for $\mathrm{NaCl}$-stressed Saccharomyces cerevisiae cells (Serrano \& Rodriguez-Navarro, 2001), that in plants with high $\mathrm{K}^{+}$to $\mathrm{Na}^{+}$ratios the $\mathrm{K}^{+}$uptake system changes to a state in which there is an increased affinity for $\mathrm{K}^{+}$thereby effectively reducing $\mathrm{Na}^{+}$influx. Thus, a lower accumulation of $\mathrm{Na}^{+}$in shoot of Prosopis juliflora and Piptedenia macrocarpa points toward increased $\mathrm{K}^{+}$selectivity of the $\mathrm{K}^{+}$uptake system. The contrary is expected for Mimosa hostilis and Leucaena lucocephala. Indeed, presumably genotypes that are most tolerant to salinity tightly regulate ion uptake across plasma membrane at rates compatible to capacity for vacuolar compartmentalization and growth at sizeable rates (Yeo \& Flowers, 1983; Flowers \& Hajibagheri, 2001). In addition, transport process at the plasma membrane and tonoplast that regulates ion influx and efflux, particularly those involved in the control of uptake and $\mathrm{Na}^{+}$vacuolar compartmentalization, are of great significance for salinity metabolic adjustment (Maathuis et al., 1996). Thus, maintenance of ion homeostasis compatible to sustained growth may result from inside negative membrane potential which, according to Binzel et al. (1988), creates a substantial thermodynamic barrier to the $\mathrm{Cl}^{-}$downhill influx even at relatively high external concentrations of this ion.

In the current study decrease in accumulation of dry matter of shoot of $\mathrm{NaCl}$ treated plants was greater than the root (Figure $1 \mathrm{~B}, 1 \mathrm{C})$. This is expected and has been found for a number of glycophytes species (Munns \& Termaat, 1986; Chessemann, 1988; Viégas et al., 2001), and it is expected to be due partly to decreasing photosynthetic rates and due partly to increasing the export of carbohydrate from shoot to root (Silveira et al., 2001).

\section{CONCLUSIONS}

1. In terms of dry matter gain Prosopis juliflora and Piptadenia macrocarpa responded best to salinity than Mimosa hostilis and Leucaena leucocephala seedlings.

2. The higher reduction in dry matter of Mimosa hostilis and Leucaena leucocephala may result from a higher accumulation in shoot of $\mathrm{Na}^{+}$and $\mathrm{Cl}^{-}$and from a lower shoot$\mathrm{K}^{+}$to $\mathrm{Na}^{+}$ratio.

3. The pattern of $\mathrm{Na}^{+}$and $\mathrm{Cl}^{-}$partitioning between shoot and root was similar for all the plants.

4. In the early seedling phase, Prosopis juliflora and Piptadenia macrocarpa species seem to have a mechanism to avoid over accumulation of $\mathrm{Na}^{+}$and $\mathrm{Cl}^{-}$. 


\section{ACKNOWLEDGEMENT}

To Conselho de Desenvolvimento Científico e Tecnológico (CNPq) for fellowship and financial support given to Ricardo Almeida Viégas and Joaquim Albenísio Gomes Silveira.

\section{LITERATURE CITED}

Binzel, M.L.; Hess, F.D.; Bresssan, R.A.; Hasegawa, P.M. Intracellular compartimentation of ions in salt adapted tobacco cells. Plant Physiology, Rockville, v.86, p.607-614, 1988.

Bottacin, A.; Cacco, G.; Saccomani, M. Nitrogen absorption and assimilation in $\mathrm{NaCl}$-resistant and $\mathrm{NaCl}$-susceptible millet genotypes (Pennisetum americanum). Canadian Journal of Botany, Ottawa, v.63, p.517-520, 1984.

Buschmann, P.H.; Vaidynathan, R.; Gassmann, W.; Shroeder, J.I. Enhancement of $\mathrm{Na}^{+}$uptake currents, time-dependent inward-rectifying $\mathrm{K}^{+}$channel currents, and $\mathrm{K}^{+}$channel transcripts by $\mathrm{K}^{+}$starvation in wheat root cells. Plant Physiology, Rockville, v.122, p.1387-1398, 2000.

Chapman, H.D.; Pratt, P.F. Methods of analysis for soils, plants and water. Belmont: Wadsworth Publishing Company, Californian Division of Agriculture Science, 1961, p.309.

Chesseman, J.M. Mechanisms of salinity tolerance in plants. Plant Physiology, Rockville, v.87, p.547-550, 1988.

Fausto, M.J.M.; Viégas, R. A.; Queiroz, J.E.; Lima Junior, A.R.; Souza, C. N.; Paulo, M.C.; Ligia, M.M.; Viégas, P.R.A.; Silveira, J.A.G.; Iza, M.A.R. Salinity induced effects on growth and total N content of Prosopis juliflora seedlings. In: Reunião Brasileira de Fertilidade do Solo e Nutrição de Plantas, 25, FERTBIO, Rio de Janeiro, 2002, CD-Rom

Flowers, T.J.; Hajibagheri, M.A. Salinity tolerance in Hordeum vulgare: ion concentrations in root cells of cultivars differing in salt tolerance. Plant and Soil, Dorderecht, v.231, p.1-9, 2001.

Ghoulam, C.; Foursy, A.; Fares, K. Effects of salt stress on growth, inorganic ions and proline accumulation in relation to osmotic adjustment in five sugar beet cultivars. Environmental and Experimental Botany, Memphis, v.47, p.39-50, 2002.

Hasegawa, P.M.; Bressan, R.A.; Zhu, J.K.; Bonert, H.J. Plant cellular and molecular responses to high salinity. Annual Review of Plant Physiology and Molecular Biology, Palo Alto, v.51, p.463-499, 2000.

Hoagland, D.R.; Arnon, D.I. The water-culture method for growing plants without soil: California Agricultural Experimental Station, 1950.347p.

Lacerda, C.F.; Cambraia, J.; Cano, M.A.O.; Ruiz, H.A. Plant growth and solute accumulation and distribution in two sorghum genotypes, under $\mathrm{NaCl}$ stress. Brazilian Journal of Plant Physiology, Campinas, v.13, n.3, p.270-284, 2001.

Lin, H.; Sandra, S.S.; Schumaker, K.S. Salt sensitivity and the activities of the H-ATPase in cotton seedlings. Crop Science, Madison, v.37, p.190-197, 1977.

Maathuis, F.J.M.; Dawn, V. F.; Smith, F.A.; Sanders, D.; Fernández, J.A.; Walker, N.A. The physiological relevance of $\mathrm{Na}^{+}$- coupled $\mathrm{K}^{+}$- transport. Plant Physiology, Rockville, v.112, p.1609-1616, 1996.
Malavolta, E.; Vitti, G.; Oliveira, S.A. Avaliação do estado nutricional das plantas. Piracicaba: POTAFOS, 1989, 201p.

Munns, R.; Termaat, A. Whole plant responses to salinity. Australian Journal of Plant Physiology, Melbourne, v.13, p.143-160, 1986.

Niu, X.; Bressan, R.A.; Hasegawa, P.M.; Pardo, J.M. Ion homeostasis in $\mathrm{NaCl}$ stress environments. Plant Physiology, Rockville, v.109, p.735-742, 1995.

Paulo, M.C.; Viégas, R.A.; Souza, C.N.; Fausto, M.J.M.; Queiroz, J.E.; Ligia, M.M.; Silveira, J.A.G.; Iza, M.A.R. Efeito da salinidade sobre a acumulação de solutos em plantas jovens de umbuzeiro. In: Reunião Brasileira de Fertilidade do Solo e Nutrição de Plantas, 25, FERTBIO, Rio de Janeiro, 2002, CD-Rom

Rascio, A.; Russo, M.; Mazzucco, L.; Platani, C.; Nicastro, G.; Di Fonzo, N. Enhaced osmotolerance of a wheat mutant selected for potassium accumulation. Plant Science, Spring, v.160, p.441-448, 2001.

Schachtman, D.; Liu, W. Molecular pieces to the puzzle of the interaction between potassium and sodium uptake in plants. Plant Science Review, Spring, v.7, p.281-289, 1999.

Serrano, R.; Rodriguez-Navarro, A. Ion homeostasis during salt stress in plants. Cell Biology, New York, v.13, p.399-404, 2001.

Silveira, J.A.G.; Melo, A.R.B.; Viégas, R.A.; Oliveira, J.T.A. Salinity-induced effects on nitrogen assimilation related to growth in cowpea plants. Environmental and Experimental Botany, Memphis, v.46, p.171-179, 2001.

Skerrtt, M.; Tyerman, S.D. A channel that allows inwardly directed fluxes of anions in protoplasts derived from wheat roots. Planta, Berlin, v.192, p.295-305, 1992.

Souza, C. N.; Viégas, R. A.; Queiroz, J.E.; Lima Junior, A.R.; Fausto, M.J.M.; Paulo, M.C.; Ligia, M.M.; Viégas, P.R.A.; Silveira, J.A.G.; Iza, M.A.R. Changes in salt stressed forest species of ion partitioning and growth responses. In: Reunião Brasileira de Fertilidade do Solo e Nutrição de Plantas, 25, FERTBIO, Rio de Janeiro, 2002, CD-Rom

Teleinskk, E.; Grunberg, K. Ion balance in tomato cultivars differing in salt tolerance. Physiologia Plantarum, Copenhagen, v.92, p.528-534, 1994.

Viégas, R.A.; Melo, A.R.B.; Silveira, J.A.G.S. Nitrate reductase activity and proline accumulation in cashew in response to $\mathrm{NaCl}$ salt shock. Brazilian Journal of Plant Physiology, Campinas, v.11, p.21-28, 1999.

Viégas, R.A.; Silveira, J.A.G. Ammonia assimilation and proline accumulation in young cashew plants during long term exposure to $\mathrm{NaCl}$-salinity. Brazilian Journal of Plant Physiology, Campinas, v.11, p.153-159, 1999.

Viégas, R.A.; Silveira, J.A.G.; Lima Junior, A.R.; Queiroz, J.E.; Fausto, M.J.M. Effects of NaCl-salinity on growth and inorganic solute accumulation of young cashew plants. Brazilian Journal of Agricultural and Environmental Engineering, Campina Grande, v.5, p.14-20, 2001.

Yeo A.R.; Flowers, T.J. Varietal differences in the toxicity of sodium ions in rice leaves. Physiologia Plantarum, Copenhagen, v.59, p.189-195, 1983.

Zhu J.K.; Liu J.; Xiong L. Genetic analysis of salt tolerance in arabdopsis: evidence for a critical role of potassium nutrition. Plant Cell, Rockville, v.10, p.1181-1191, 1998. 